\title{
Corrosion Behavior of Copper Based Heat Exchanger Tube in Waters of Bangladesh Region at Varied Temperature and Flow Velocity
}

\author{
M. Muzibur Rahman ${ }^{*}$ and S. Reaz Ahmed ${ }^{2}$ \\ ${ }^{1}$ Department of Naval Architecture \& Marine Engineering, Military Institute of Science and Technology, Dhaka, Bangladesh \\ 2 Department of Mechanical Engineering, Bangladesh University of Engineering and Technology, Dhaka, Bangladesh
}

emails: $1^{*}$ muzib1061@name.mist.ac.bd; ${ }^{2}$ srahmed@me.buet.ac.bd

\section{ART I CLE IN F O}

\section{Article History:}

Received: $30^{\text {th }}$ April 2020

Revised: 06 $6^{\text {th }}$ June 2020

Accepted: 04 $4^{\text {th }}$ August 2020

Published: $16^{\text {th }}$ December 2020

\section{Keywords:}

Corrosion

Copper tube

Heat exchanger

River vs sea water

Life span estimation

\begin{abstract}
A B S T RA C T
Heat exchangers used in the ships are mostly of water-cooled shell and tube type, whose tube stacks are made of copper-based materials due to the requirement of high corrosion resistance and high thermal conductivity. Even though, the copper made heat exchanger tubes do fail on board ships because of corrosion. More point of contention arises when it is manufactured by companies that have limited supporting data and documentations. In this context, the present paper investigates the corrosion behavior of copper tubes of heat exchanger to assess the life span of the tube stack for on-board applications. A series of experiments have been undertaken to investigate the corrosion rates of copper tubes in sea water and river water with flow velocity of $1.0 \mathrm{~m} / \mathrm{s}, 1.5 \mathrm{~m} / \mathrm{s}$ and $2.0 \mathrm{~m} / \mathrm{s}$ for the tube side entry temperature of $20^{\circ} \mathrm{C}$. The same experiments have been repeated for the shell side temperatures of $20^{\circ} \mathrm{C}, 40^{\circ} \mathrm{C}, 60^{\circ} \mathrm{C}$ and $80^{\circ} \mathrm{C}$. The investigations have revealed that the corrosion in sea water is about three times higher than that of river water. The increases in temperature and flow velocity have increased the rate of corrosion to a significant level contributing to shorten the life span.
\end{abstract}

(c) 2020 MIJST, All rights reserved.

\section{INTRODUCTION}

Copper is chosen for the tube stacks of heat exchanger due to its superior thermo-mechanical properties such as thermal conductivity, resistance to corrosion, strength, and formability (Collini, 2012). It may be mentioned that copper is located in the periodic table in line of noble metals, and thus copper is considered as immune from corrosion. The corrosion immunity of copper is also based on a postulation on the existence of native copper in the earth's crust (Davis, 2001). In the atmosphere, a very thin layer of brownish-green or greenish blue in color known as patina is formed (Graedel et al., 1987; Leygraf et al., 2019). Established patina becomes stable and remains as a permanent part of the copper object in the atmosphere. Examples of the corrosion resistance of copper materials are artifacts that have been found in nearly pristine condition after having been buried in the earth for thousands of years, and copper roofing in rural atmosphere has been found to corrode at rates of less than $0.4 \mathrm{~mm}$ in 200 years (Cramer \& Covino, 2005, pp. 125). But, in water, copper corrodes due to number of factors as considered differently by different researchers (Hedin et al., 2018; Hultquist et al., 2009, 2011 \& 2015; Hultquist, 2015; Simpson \& Schenk, 1987; Szakálos et al., 2007). According to a group of researchers (Hultquist et al. 2015), the oxygen is consumed through hydrogen-oxygen reaction and the hydrogen is coming out from the reaction of copper with water. It is considered that the hydrogenoxygen reaction is faster than the formation rate of the initially atomic hydrogen from the corrosion reaction itself on copper (Hultquist et al., 2015) and it is not possible to detect the hydrogen released from copper if the supply rate of oxygen to the surface exceeds the rate of hydrogen generation; and copper is considered erroneously as corrosion resistant (Hultquist et al. 2009 \& 2011). On the other hand, few researchers (Simpson \& Schenk, 1987; Hedin et al., 2018) have expressed the disagreement on the corrosiveness of copper in pure water.

However, corrosion of copper in sea water is accepted by all the mariners as well as researchers due to aggressiveness of ingredients like dissolved oxygen, chloride, sulphate, dissolved solids, suspended solids etc. 
present in the sea water (Abdallah et al., 2009; Farro et al., 2009; Francis, 2010; Gudas \& Hack, 1979; Nunez et al., 2005; Orozco-Cruz et al., 2017; Pehkonen et al., 2002; Rahmanto et al., 2002; Schumacher, 1979; Zakowski et al., 2014). Beside the aggressive ingredients, few dynamic parameters such as velocity, pressure, temperature, conductivity, $\mathrm{pH}$ value, etc. are playing some role in the corrosion behavior of metal in contact with sea water (Gerasimov \& Rozenfeld, 1958; Kong et al., 2017; Kristiansen, 1977; Lee et al., 2016; Mor \& Beccaria, 1979; Poulson, 1993; Roy et al., 2018; Sabri et al., 2012; Utanohara \& Murase, 2019; Wan et al., 2012; Yatsenko et al., 1999). Moreover, various types of corrosion attacks can occur to the marine equipment made up of copper materials exposed to sea water. In view of above, the corrosion behaviors of metals including copper coming in contact with sea water especially during operations at elevated temperature along with significant flow velocity need to be characterized at specific water and environment conditions to assess the performance of marine machinery (Pehkonen et al., 2002).

Bangladesh being a maritime nation with long glory of shipbuilding heritage must have development in marine sector (Rahman, 2017). At the same time, a good number of vessels are plying in the inland water ways and at the coast of Bangladesh, which use river/sea water in heat exchangers to cool fresh water and lubricating oil of marine engines for propulsion and power generation. This requirement pushes the stake holders to look for reference data to have design allowances and life span assessment of marine equipment especially the heat exchanger on the issue of corrosion. But, unfortunately, necessary data for making decisions based on experimental results on corrosion are neither available to mariners nor even to local shipbuilding industries. One of such cases is the reliability problem due to absence of data of locally manufactured shell and tube type heat exchanger having copper tube stack.

At this juncture, it is very important to carry out the study on characterization of corrosion behavior of materials commonly used on board ships, which are especially coming in contact of sea water so that the shipbuilding can be enhanced as the real 'thrust sector' of national economic progress with the implementation plan of sustainable development goals (SDGs). To this effect, the present work is an attempt to investigate the corrosion behavior of locally made copper heat exchanger tubes to be used in the inland river water as well as coastal sea water environment of Bangladesh region.

\section{MATERIALS AND EXPERIMENTAL DETAILS}

To investigate the corrosion behavior of copper-based tube stack of shell and tube type heat exchanger for onboard ships with marine propulsion and power generation engines, two bundles of copper tubes manufactured in a local shipyard of Bangladesh for coastal vessels were collected. Each tube was of $400 \mathrm{~mm}$ length, $9.525 \mathrm{~mm}$ outer diameter and $1.245 \mathrm{~mm}(18 B W G)$ wall thickness. Before the corrosion testing experiments, the chemical composition of the tube material was tested using XRF machine (model: Olympus DPO-2000-CC having silicon drift detector for element identification) and microstructures were observed using computer interfaced Optical Electronic Microscope (model: Nikon BW-S500 having 4.19 Mpixel camera). The chemical composition of tube is found to be of $99.934 \% \mathrm{Cu}, 0.019 \% \mathrm{Si}$, $0.016 \% \mathrm{P}, 0.018 \% \mathrm{Fe}$, and $0.013 \% \mathrm{Ni}$.

The heat exchangers for ships are supposed to cool the engine lubricating oil and jacket water through an engine driven pump that supplies water from river or sea according to the plying location of the ship. The designated ship is designed to be operated from Khulna to Chittagong, and thus the heat exchangers would use inland water near Khulna area for river cruise as well as sea water during crossing the Bay of Bengal up to Chittagong. Considering the operational requirements of the ship, two identical experimental set-up arrangements were prepared, i.e., one for river water and another for sea water. Accordingly, 5000-liter water from each location, i.e., Rupsha River and the Bay of Bengal was collected for the experimental purpose. The laboratory test result of the collected water is presented in Table 1.

Table I

Contents and properties of water used for investigation

\begin{tabular}{lll}
\hline \hline Parameter & $\begin{array}{l}\text { River } \\
\text { Water }\end{array}$ & $\begin{array}{l}\text { Sea } \\
\text { Water }\end{array}$ \\
\hline $\mathrm{pH}$ & 7.08 & 7.14 \\
Total Dissolved Solids (mg/liter) & 250 & 28000 \\
Total Suspended Solids (mg/liter) & 15 & 48 \\
Chloride (mg/liter) & 4500 & 21000 \\
Sulphate (mg/liter) & -- & 1320 \\
Dissolved Oxygen (mg/liter) & 6.55 & 7.29 \\
Electric Conductivity $(\mu \mathrm{S} / \mathrm{cm})$ & 450 & 48000 \\
\hline \hline
\end{tabular}

The components for each experimental set-up include pumps, tanks, flexible pipes, fittings, manifold, heat exchanger tubes, flow meter, thermometers, thermostat, relay, electric heater, etc. The straight tubes were placed with the removable headers and manifolds in the experimental set-up to observe their corrosion behavior using gravimetric method. The operating temperature of the heat exchanger of a marine engine remains normally from $45^{\circ} \mathrm{C}$ to $75^{\circ} \mathrm{C}$ on shell side for the temperature of lubricating oil and jacket water due to variation of engine load, and in the tube side, the cooling water temperature is from $18^{\circ} \mathrm{C}$ to $30^{\circ} \mathrm{C}$ due to seasonal variation. Therefore, experiments were carried out for the shell side temperatures of $20^{\circ} \mathrm{C}, 40^{\circ} \mathrm{C}, 60^{\circ} \mathrm{C}$ and $80^{\circ} \mathrm{C}$ so that corrosion behavior against these temperatures can be obtained. For the experiment at $20^{\circ} \mathrm{C}$, normal fresh water was passed through the shell side, and for $40^{\circ} \mathrm{C}, 60^{\circ} \mathrm{C}$, and $80^{\circ} \mathrm{C}$, hot water was circulated using electric heaters to maintain the temperature during each experiment. The cooling water was stored in the open type tank for natural air cooling and an arrangement was made on the return line of tube side cooling water to spray in the atmosphere for maintaining the normal temperature. Both hot water and cooling water were reused with closed circuit arrangements as shown in Figure 1. 


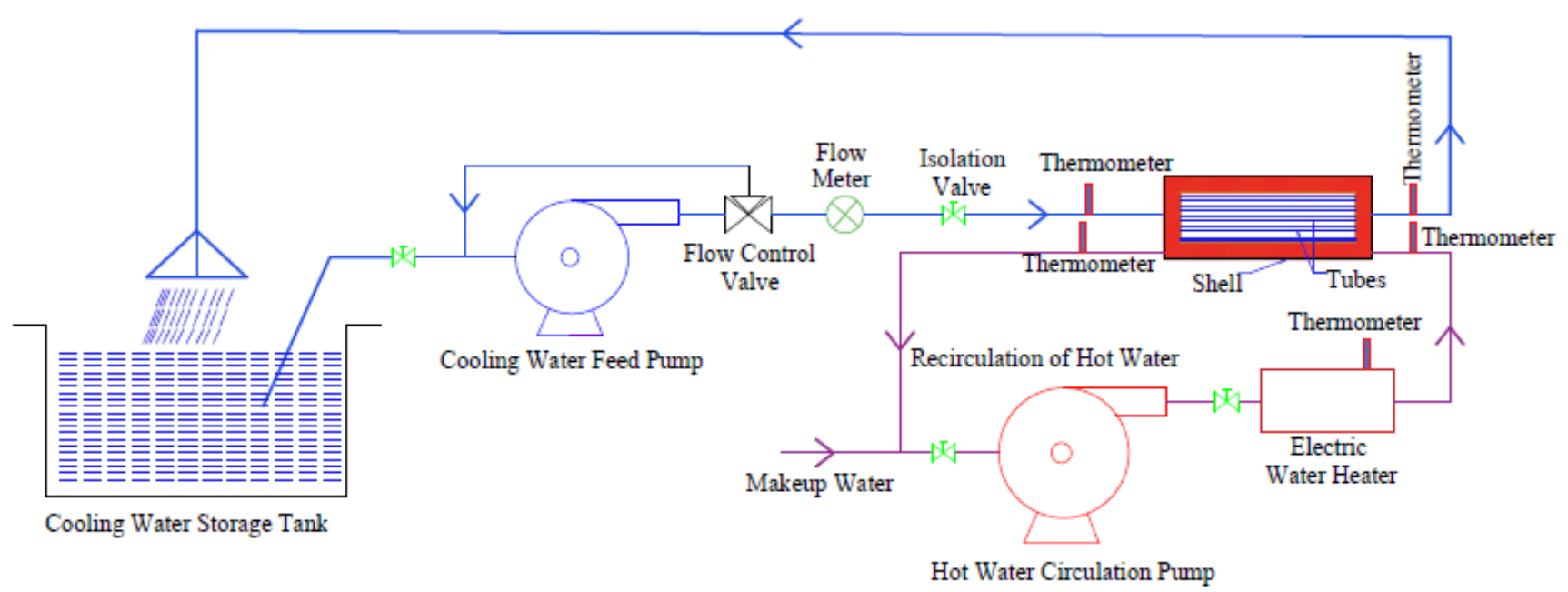

Figure 1: Layout of Experimental Setup Arrangement

After every designated period, the pump was stopped for a very short time; tubes were removed from the system and cleaned in distilled water to investigate weight, thickness and microstructures and fitted back. The weighing machine (model: Sartorius Entris 224-1S having pan diameter of $90 \mathrm{~mm}$ with the maximum weighing capacity of $220 \mathrm{~g}$ ) of $0.1 \mathrm{mg}$ precision and ultrasonic thickness gauge (model: CG100 ABDL having measurement resolution of $0.01 \mathrm{~mm}$ ) were used for the experimental purposes. The test readings were taken after one day, three days, six days, twelve days, eighteen days, twenty-four days and finally thirty days. On completion of thirty days operation, the changes in weight and dimensions were found to be very nearer to the immediately previous readings and thus it was considered as one complete cycle of the experiment. The same experiment was repeated for different operating temperatures and flow velocities. Likewise, three cycles of experiments were conducted to get the mean corrosion so that life span of heat exchanger tube could be calculated. The mathematical expressions used for calculating weight loss and corrosion rate are following the ASTM manual as given below (Baboian, 2005).

Amount (weight) loss of metal:

$\Delta W=\frac{\left(W_{o}-W_{f}\right)}{A}$

Corrosion rate:

$R_{\text {corr }}=\frac{(K \times \Delta W)}{(\rho \times T)}$

Where,

$$
\begin{array}{ll}
W_{o} & =\text { Initial weight }(\mathrm{g}) \\
W_{f} & =\text { Weight after designated period }(\mathrm{g}) \\
\Delta W & =\text { Weight loss per exposed surface area }\left(\mathrm{g} / \mathrm{cm}^{2}\right) \\
A & =\text { Exposed surface area }\left(\mathrm{cm}^{2}\right) \\
R_{\text {corr }} & =\text { Corrosion Rate }(\text { mm per year, i.e., } \text { mmpy) } \\
K & =\text { Unit conversion factor } \\
\rho & =\text { Density of metal }\left(\mathrm{g} / \mathrm{cm}^{3}\right) \\
T & =\text { Exposed time }(\text { day) }
\end{array}
$$

\section{RESULTS AND DISCUSSION}

\section{A. Trend Analysis of Corrosion for River Water Environment}

In chemical terms, copper is demarcated in the noble metal family and considered as highly resistant to corrosion and oxidation. Copper's resistance to corrosion is attributed mainly to a thin oxide film called patina that forms on the surface of copper when exposed to a medium. This patina firmly adheres to the outer surface of the copper material and can protect the underlying copper layers from further corrosion (Graedel et al., 1987; Leygraf et al., 2019). However, the water chemistry and other factors cause the medium increasingly aggressive towards copper breaking up the patina to some extent. This phenomenon is comprehensive in the gravimetric analysis of the present experiment. Here, the loss of specimen weight per unit surface area $\left(\mathrm{g} / \mathrm{cm}^{2}\right)$ exposed to the corrosive media is calculated using Equation (1) for four temperatures that are important to the operations of marine engines. Figure 2 presents the copper leaching in contact of river water against the period of operations while flowing through the copper tubes of heat exchanger at a velocity of $1.0 \mathrm{~m} / \mathrm{s}$ for the external shell temperatures of $20^{\circ} \mathrm{C}, 40^{\circ} \mathrm{C}, 60^{\circ} \mathrm{C}$, and $80^{\circ} \mathrm{C}$. It is observed that the weight loss is increased with the increase of operating period, and all the curves are steeper at the initial tenure of attack with gradual flattening over further period. After 30 days operations, the weight loss curves have no incremental gradient and thus the slopes reach towards almost zero. At the same time, weight loss is found to be higher for higher temperature over the whole operating period. On completion of one day's operation, weight loss per unit exposed surface for the operating temperatures of $20^{\circ} \mathrm{C}, 40^{\circ} \mathrm{C}, 60^{\circ} \mathrm{C}$, and $80^{\circ} \mathrm{C}$ are found to be $229 \times 10^{-6} \mathrm{~g} / \mathrm{cm}^{2}, 314 \times 10^{-6} \mathrm{~g} / \mathrm{cm}^{2}$, $399 \times 10^{-6} \mathrm{~g} / \mathrm{cm}^{2}$, and $492 \times 10^{-6} \mathrm{~g} / \mathrm{cm}^{2}$, respectively, and after 30 days operations, the copper tubes have lost $1978 \times 10^{-6} \mathrm{~g} / \mathrm{cm}^{2}, 2139 \times 10^{-6} \mathrm{~g} / \mathrm{cm}^{2}, 2249 \times$ $10^{-6} \mathrm{~g} / \mathrm{cm}^{2}$, and $2343 \times 10^{-6} \mathrm{~g} / \mathrm{cm}^{2}$, respectively.

Therefore, after 30 days' operation, weight loss on average is increased by $8.63,6.81,5.64$, and 4.76 times from the weight loss of the first day. For the change in operating temperature from $20^{\circ} \mathrm{C}$ to $80^{\circ} \mathrm{C}$, the weight loss is 
increased on average by $18.45 \%$. In other words, the average weight loss is increased by $6.98 \times 10^{-6} \mathrm{~g} / \mathrm{cm}^{2} /$ ${ }^{\circ} \mathrm{C}$. The average value of change in weight loss has been taken for the change in operating temperature from $20^{\circ} \mathrm{C}$ to $40^{\circ} \mathrm{C}$, from $40^{\circ} \mathrm{C}$ to $60^{\circ} \mathrm{C}$, and from $60^{\circ} \mathrm{C}$ to $80^{\circ} \mathrm{C}$. It is because the effect of change in thermal condition on corrosion is not linear, rather in many cases it is complex phenomenon and the corrosion does not have stable correlation with respect to temperature (Kong et al., 2017; Kuźnicka, 2009; Lee et al., 2016; Melchers, 2001; Mor \& Beccaria, 1979; Wan et al., 2012).

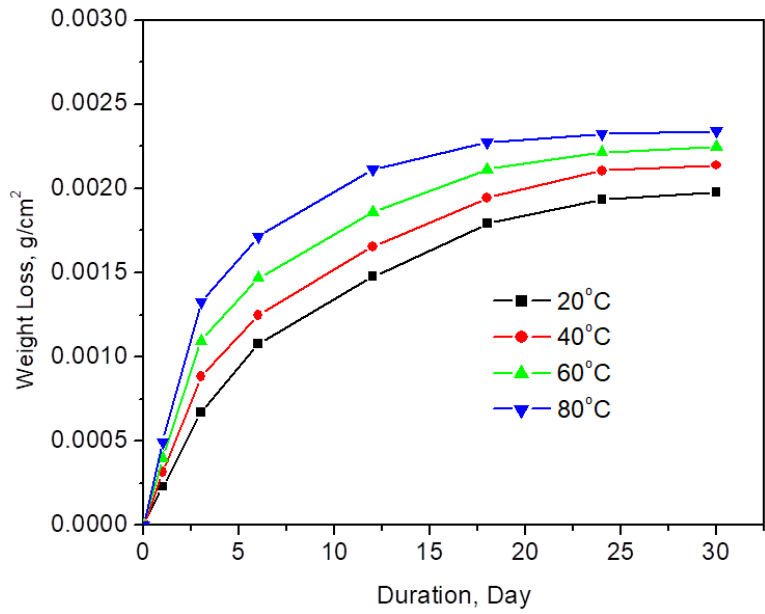

Figure 2: Weight loss per unit exposed surface against operating period for operating temperatures of $20^{\circ} \mathrm{C}, 40^{\circ} \mathrm{C}$, $60^{\circ} \mathrm{C}$, and $80^{\circ} \mathrm{C}$ with the river water flow velocity of $1.0 \mathrm{~m} / \mathrm{s}$

Basically, the river water contains certain amount of dissolved oxygen, total dissolved solids (TDS), total suspended solids (TSS) and chlorides as observed through laboratory tests, and thus the environment is aggressive enough to make the copper tube susceptible to corrosion. Further notable issues are general (uniform or galvanic) corrosion over the exposed surface area because of electrochemical phenomenon, erosion corrosion due to flow velocity of water through the tube and thermal effect due to variation in operating temperatures. There is a close relation between solution conductivity and corrosion reactions also. Again, the electrolyte conductivity increases with the increase in temperature due to enhanced mobility of ions (Gerasimov 1958; Wang et al., 2016). The conductivity of most natural water increases with the increase in temperature by 2 to 3 percent per degree Celsius (Miller, 1988). Due to higher conductivity at higher temperature, copper particles are released from the patina, and some copper atoms move away with the flow of water; but some atoms stay at the vicinity if the flow of water is not too turbulent. It results in the formation of copper hydroxychloride due to presence of chloride in the water (Abdallah et al., 2009). As a result, significant increase in weight loss is observed for the operating temperature of $60^{\circ} \mathrm{C}$ and $80^{\circ} \mathrm{C}$.

Based on the loss of weight, corrosion rates have been calculated using Equation (2) at the operating temperatures of $20^{\circ} \mathrm{C}, 40^{\circ} \mathrm{C}, 60^{\circ} \mathrm{C}$, and $80^{\circ} \mathrm{C}$ for different time intervals up to 30 days. Figure 3 depicts that the corrosion rate is the highest at the initial attack period, and then, it is reduced gradually but nonlinearly for all operating temperatures with the flow velocity of $1.0 \mathrm{~m} / \mathrm{s}$

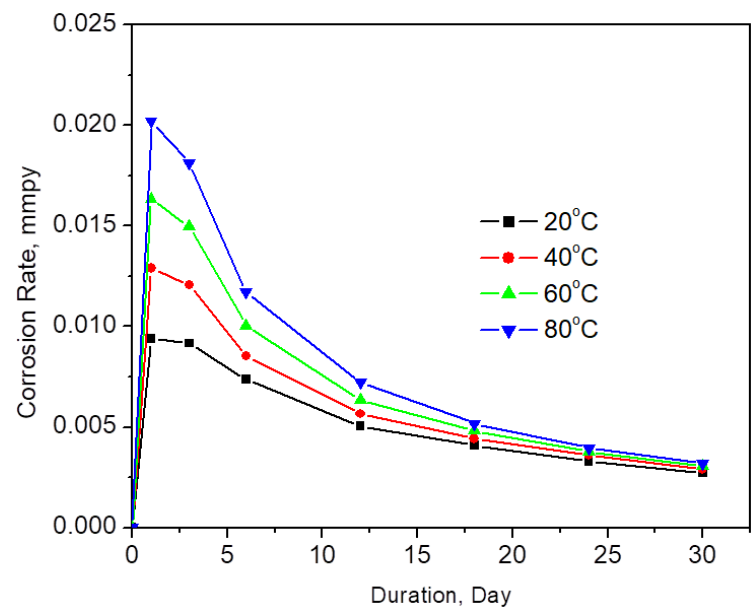

Figure 3: Corrosion rate against corrosion period for the variation of operating temperature with the river water flow velocity of $1.0 \mathrm{~m} / \mathrm{s}$

After 30 days of operations, corrosion rates are found to be almost steady showing minimum values. Copper reacts with dissolved oxygen and forms at first cuprous oxide which reacts with oxygen to procedure cupric oxide. These copper oxides react with the available anions in the vicinity to form compounds further (Imai et al., 2009; Lee et al., 2016; Zakowski et al., 2014). The time delay in the formation of copper oxides and development period of the patina in stable state might be the reason for the highest corrosion rate to be occurred at the initial attack period. The thermal effect on corrosion rate is as like that of weight loss, i.e., higher corrosion rate is witnessed for higher operating temperature.

It is observed that the corrosion rate gets affected by the velocity of fluid flow inside the tube also (Kuźnicka, 2009; Utanohara \& Murase, 2019). Figure 4 illustrates the effect of changing flow velocity of $1.0 \mathrm{~m} / \mathrm{s}, 1.5 \mathrm{~m} / \mathrm{s}$, and $2.0 \mathrm{~m} / \mathrm{s}$ on the rate of corrosion at the operating temperature of $80^{\circ} \mathrm{C}$. Since the cooling water flow velocity for marine engines are normally maintained within $2.0 \mathrm{~m} / \mathrm{s}$ to ensure the proper suction of the pump from the sea under the conditions of all six degrees of ship motion, the effect of velocity on corrosion rate is not that significant. However, for the initial attack, the corrosion rates for the flow velocity of $1.0 \mathrm{~m} / \mathrm{s}, 1.5 \mathrm{~m} / \mathrm{s}$, and $2.0 \mathrm{~m} / \mathrm{s}$ are found to be $20.2 \times 10^{-3} \mathrm{mmpy}, 20.9 \times$ $10^{-3} \mathrm{mmpy}$, and $21.6 \times 10^{-3} \mathrm{mmpy}$ respectively, i.e., the corrosion rate has been increased by $6.8 \%$ for the change of flow velocity from $1.0 \mathrm{~m} / \mathrm{s}$ to $2.0 \mathrm{~m} / \mathrm{s}$.

\section{B. Trend Analysis of Corrosion for Sea Water Environment}

Like the river water environment, the loss of specimen weight per unit surface area exposed to the corrosive environment of sea water is calculated using Equation (1) for four operating temperatures and the result of 30 days operation is presented in Figure 5. Here also, the weight loss $\left(\mathrm{g} / \mathrm{cm}^{2}\right)$ is taken as the copper leached due to overall corrosion effect in contact of sea water for the external shell temperatures of $20^{\circ} \mathrm{C}, 40^{\circ} \mathrm{C}, 60^{\circ} \mathrm{C}$, and $80^{\circ} \mathrm{C}$, while the sea water is flowing through the copper tube of heat exchanger at a velocity of $1.0 \mathrm{~m} / \mathrm{s}$. It is observed that the 
weight loss is increased with the increase of operating period, and all the curves have very high slope at the initial attack period with gradual flattening over the long operating period as like that of river water. After 30 days operations, the weight loss curves have no incremental gradient and thus the slopes tend to almost zero. At the same time, weight loss is found to be higher for higher operating temperature over the whole operating period. As such, on completion of one day's operation, weight loss for the operating temperatures of $20^{\circ} \mathrm{C}, 40^{\circ} \mathrm{C}, 60^{\circ} \mathrm{C}$, and $80^{\circ} \mathrm{C}$ are found to be $1078 \times 10^{-6} \mathrm{~g} / \mathrm{cm}^{2}, 1247 \times 10^{-6} \mathrm{~g} /$ $\mathrm{cm}^{2}, 1468 \times 10^{-6} \mathrm{~g} / \mathrm{cm}^{2}$, and $1519 \times 10^{-6} \mathrm{~g} / \mathrm{cm}^{2}$, respectively, and after 30 days operations, the sample samples have lost $2218 \times 10^{-6} \mathrm{~g} / \mathrm{cm}^{2}, 2385 \times 10^{-6} \mathrm{~g} /$ $\mathrm{cm}^{2}, 2580 \times 10^{-6} \mathrm{~g} / \mathrm{cm}^{2}$, and $2835 \times 10^{-6} \mathrm{~g} / \mathrm{cm}^{2}$, respectively. After 30 days' operations, the weight loss values in sea water have been increased by $2.02,1.91$, 1.76, and 1.87 times than those of the first day's operation against the operating temperatures of $20^{\circ} \mathrm{C}, 40^{\circ} \mathrm{C}, 60^{\circ} \mathrm{C}$, and $80^{\circ} \mathrm{C}$, respectively. For the change in operating temperature from $20^{\circ} \mathrm{C}$ to $80^{\circ} \mathrm{C}$, weight loss is increased on average by $29.96 \%$. In other words, the average weight loss in sea water is increased by $10.35 \times 10^{-6} \mathrm{~g} / \mathrm{cm}^{2} /{ }^{\circ} \mathrm{C}$.

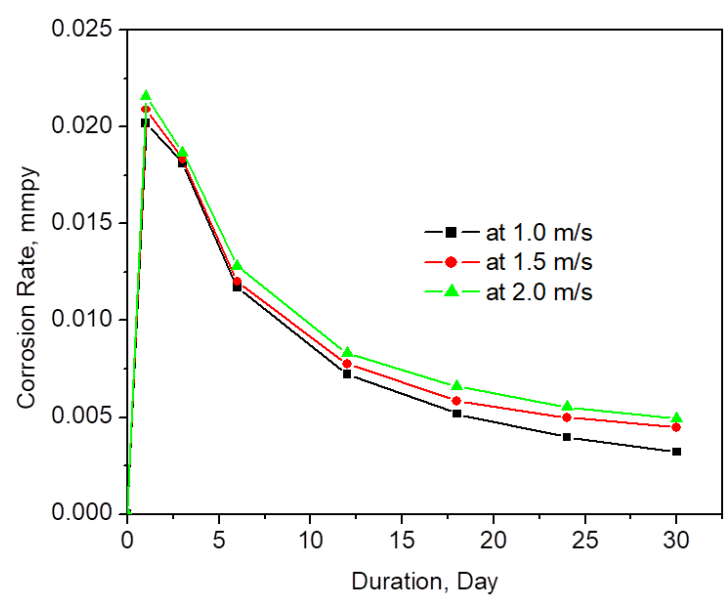

Figure 4: Corrosion rate against corrosion period for the variation of river water flow velocity at the operating temperature of $80^{\circ} \mathrm{C}$

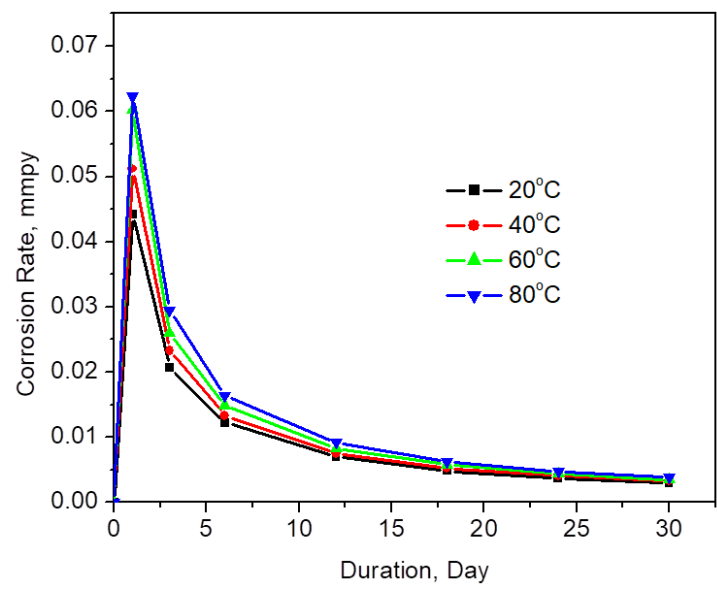

Figure 5: Weight loss per unit exposed surface against operating period for operating temperatures of $20^{\circ} \mathrm{C}, 40^{\circ} \mathrm{C}$, $60^{\circ} \mathrm{C}$ and $80^{\circ} \mathrm{C}$ with the sea water flow velocity of $1.0 \mathrm{~m} / \mathrm{s}$

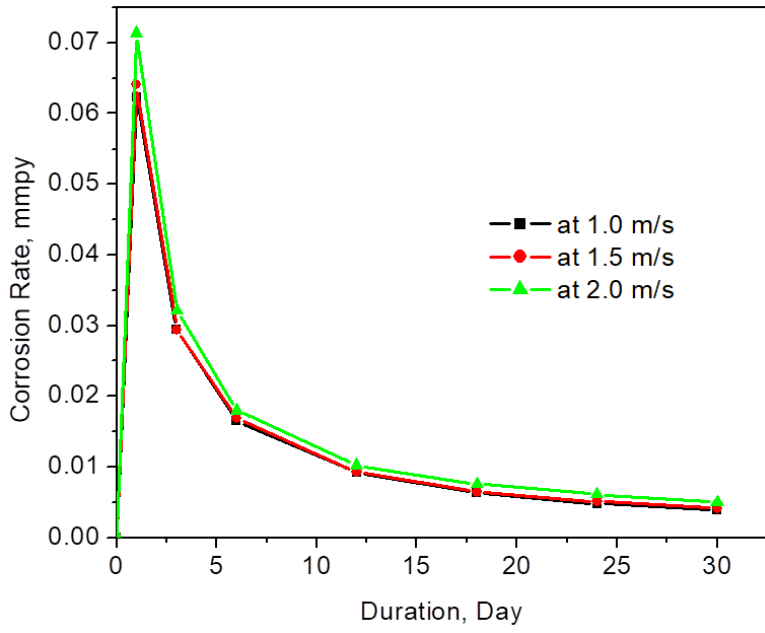

Figure 6: Corrosion rate against corrosion period for the variation of operating temperature with the sea water flow velocity of $1.0 \mathrm{~m} / \mathrm{s}$

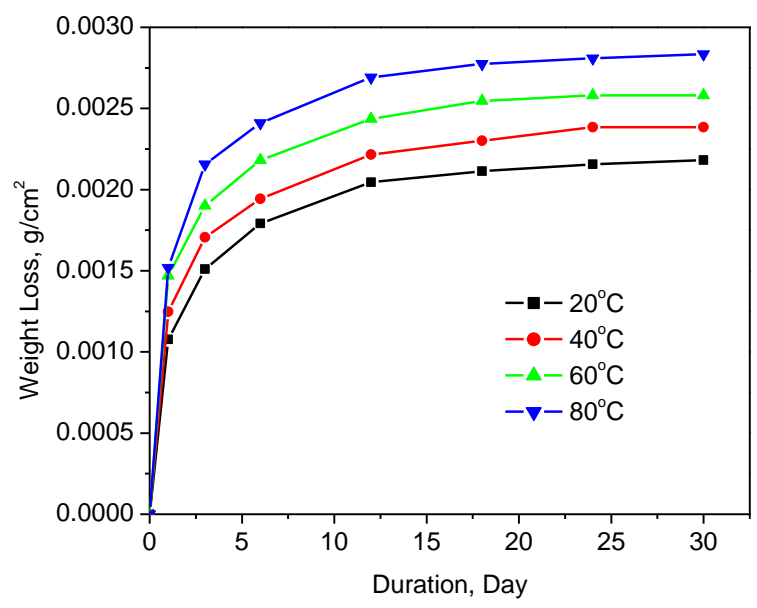

Figure 7: Corrosion rate against corrosion period for the variation of sea water flow velocity at the operating temperature of $80^{\circ} \mathrm{C}$

The sea water contains dissolved oxygen of $7.29 \mathrm{mg} /$ liter, TDS of $28000 \mathrm{mg} /$ liter, TSS of $48 \mathrm{mg} /$ liter, and chlorides of $21000 \mathrm{mg} /$ liter, and it has conductivity of $48000 \mu \mathrm{S} / \mathrm{cm}$ as perceived through laboratory tests. Thus, the sea water environment is highly aggressive to make copper susceptible to corrosion with no doubt once some level of corrosion has been observed in river water. In addition, the velocity of sea water through the heat exchanger tube and the temperature of the shell side water are important factors contributing on corrosion as to that of river water. As a result, significant level of weight loss is observed in sea water environment as shown in Figure 5.

Like that of river water, corrosion rates in sea water have been calculated using Equation (2) at the four operating temperatures for different time intervals up to 30 days. Figure 6 elucidates that the corrosion rate is found to be the highest at the initial attack period and then reduced gradually but nonlinearly with the increase of operating period as happened for river water in all operating temperatures. After 30 days of operations, corrosion rates are found to be almost steady showing minimum values. Here, the magnitude of maximum values of corrosion rates 
obtained for four operating temperatures are $44.2 \times$ $10^{-3}$ mmpy , $51.2 \times 10^{-3} \mathrm{mmpy}, 60.2 \times 10^{-3} \mathrm{mmpy}$, and $62.3 \times 10^{-3} \mathrm{mmpy}$, respectively. It indicates that the life span of a copper tube stack in heat exchanger is affected for a considerable period based on corrosion rate.

In the present experiment, the variation of the sea water flow velocity, i.e., $1.0 \mathrm{~m} / \mathrm{s}, 1.5 \mathrm{~m} / \mathrm{s}$, and $2.0 \mathrm{~m} / \mathrm{s}$, results in change in corrosion rates as shown in Figure 7 . The rate of corrosion has been found to be increased in sea water environment with the increase of flow velocity over the whole period of investigation. For the initial attack period, the corrosion rates at sea water for flow velocity of $1.0 \mathrm{~m} / \mathrm{s}, 1.5 \mathrm{~m} / \mathrm{s}$, and $2.0 \mathrm{~m} / \mathrm{s}$ are found to be $62.3 \times$ $10^{-3} \mathrm{mmpy} \quad, \quad 64.1 \times 10^{-3} \mathrm{mmpy} \quad, \quad$ and $71.4 \times$ $10^{-3} \mathrm{mmpy}$, respectively. Therefore, the corrosion rate for the change of flow velocity from $1.0 \mathrm{~m} / \mathrm{s}$ to $2.0 \mathrm{~m} / \mathrm{s}$ is increased by $14.5 \%$, which is significant and has bearing on the operational life of the heat exchanger. Corrosion rate has been affected by velocity variation at sea water condition due to mainly high values of TDS and TSS which cause the erosion corrosion also (Kuźnicka, 2009).

\section{Comparative Corrosion in River and Sea Water}

The cooling water properties as presented in Table 1 indicate that the $\mathrm{pH}$ values and dissolved oxygen are very closer for both river water and sea water, so their contribution would have been nearer on corrosion behavior of copper tube. But the sea water has significantly higher values of TDS $(28000 \mathrm{mg} /$ liter $)$, chloride $(21000 \mathrm{mg}$ / liter ), sulfate ( $1320 \mathrm{mg} /$ liter $)$ and conductivity $(48000 \mu \mathrm{S} / \mathrm{cm})$ than those of the river water, and thus the sea water is more corrosive than the river water.

Figure 8 illustrates the maximum values of corrosion rates in sea water side by side that in river water at the operating temperatures of $20^{\circ} \mathrm{C}, 40^{\circ} \mathrm{C}, 60^{\circ} \mathrm{C}$, and $80^{\circ} \mathrm{C}$ for flow velocity of $1.0 \mathrm{~m} / \mathrm{s}$, which indicates that the temperature has considerable effects on the corrosion in both the waters. The corrosion rate is increased with the increase in operating temperature from $20^{\circ} \mathrm{C}$ to $40^{\circ} \mathrm{C}$, from $40^{\circ} \mathrm{C}$ to $60^{\circ} \mathrm{C}$, and from $60^{\circ} \mathrm{C}$ to $80^{\circ} \mathrm{C}$ by $37.02 \%, 27.02 \%$, and $23.41 \%$ respectively for river water. On the other hand, the corrosion rate is increased with the increase in operating temperature from $20^{\circ} \mathrm{C}$ to $40^{\circ} \mathrm{C}$, from $40^{\circ} \mathrm{C}$ to $60^{\circ} \mathrm{C}$ and from $60^{\circ} \mathrm{C}$ to $80^{\circ} \mathrm{C}$ by $15.74 \%, 17.69 \%$, and $3.47 \%$ respectively for sea water. It is noticed that corrosion rates are increasing in both the environment, but there is a big gap in the incremental values in two corresponding environments. Moreover, no linearity in the increment of corrosion rate against temperature is observed. Another point to note that the corrosion rates in sea water are found to be $4.70,3.97,3.68$, and 3.09 , times higher than that of river water for the corresponding operating temperatures of $20^{\circ} \mathrm{C}, 40^{\circ} \mathrm{C}, 60^{\circ} \mathrm{C}$, and $80^{\circ} \mathrm{C}$, respectively.

Figure 9 demonstrates the maximum values of corrosion rates in sea water side by side that in river water for the flow velocities of $1.0 \mathrm{~m} / \mathrm{s}, 1.5 \mathrm{~m} / \mathrm{s}$, and $2.0 \mathrm{~m} / \mathrm{s}$ at the operating temperature of $80^{\circ} \mathrm{C}$. The corrosion rates in sea water are found to be almost three times higher than that of river water for all three flow velocities, i.e., $1.0 \mathrm{~m} / \mathrm{s}$,
$1.5 \mathrm{~m} / \mathrm{s}$ and $2.0 \mathrm{~m} / \mathrm{s}$. However, the corrosion rate is increased with the increase in flow velocity in both the environments. For river water, the corrosion rate is increased for the change of velocity from $1.0 \mathrm{~m} / \mathrm{s}$ to $1.5 \mathrm{~m} / \mathrm{s}$ and from $1.5 \mathrm{~m} / \mathrm{s}$ to $2.0 \mathrm{~m} / \mathrm{s}$ by $3.5 \%$, and $3.3 \%$, respectively. For sea water environment, the corresponding increments in corrosion rate are $2.8 \%$ and $11.4 \%$. Therefore, no linear relation has been observed for velocity variation also.

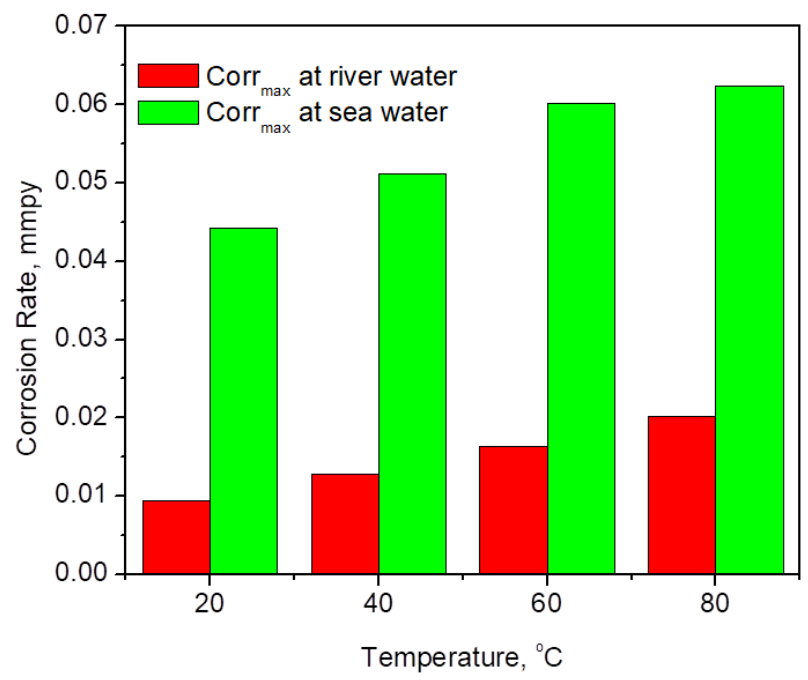

Figure 8: The maximum values of corrosion rate against operating temperatures for river water and sea water with the flow velocity of $1.0 \mathrm{~m} / \mathrm{s}$

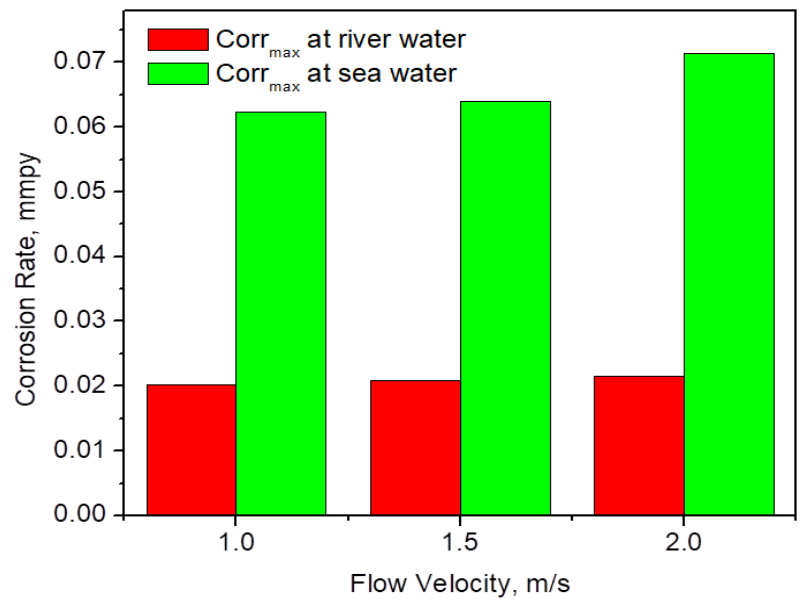

Figure 9: The maximum values of corrosion rate against flow velocity for river water and sea water for the operating temperature of $80^{\circ} \mathrm{C}$

\section{Microstructural Observation}

The microstructures observed through OEM before carrying out the corrosion test without etching, after corrosion test for 30 days in river water and after corrosion test for 30 days in sea water are presented as Figure 10 (a), (b), and (c) respectively. Micrograph shown as Figure 10(a) configures smooth and regular microstructure of copper material. Figure 10(b) depicts sign spots of combined uniform, pitting and erosion corrosion occurred by the river water for the duration of 30 days with the flow velocity of $1.0 \mathrm{~m} / \mathrm{s}$. On the copper surface, water is bonded to a first layer copper atom by the oxygen electrons. This surface offers easy interaction between the hydrogen atoms of water and the topmost copper atoms 
and results in this microstructure. Similarly, Figure 10(c) elucidates huge number of spots indicating different kinds of corrosion that occurred by the sea water for the duration of 30 days with the flow velocity of $1.0 \mathrm{~m} / \mathrm{s}$. The chloride ions present in the sea water environment have resulted in breakage of the patina surface layer and aggravated the corrosion (Srivastava \& Balasubramaniam, 2005). For the variation of operating temperature and flow velocity, no significant differences have been observed in the microstructures and as such those micrographs have not been shown here.
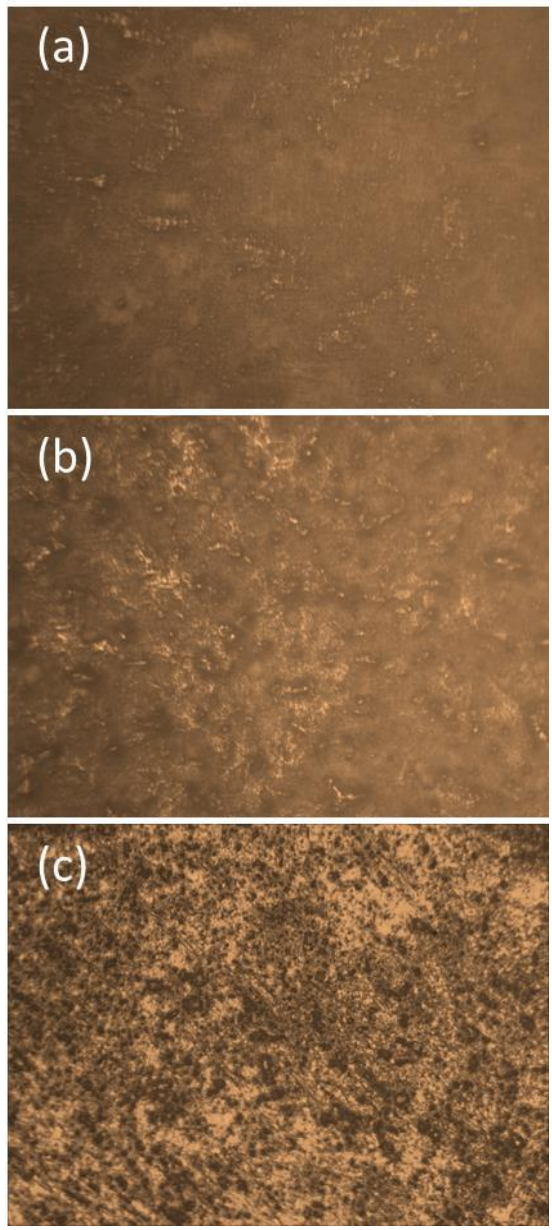

Figure 10: Micrographs with the magnification factor of $320 x$ : (a) before carrying out the corrosion test without etching, (b) after corrosion test for 30 days in river water, and

(c) after corrosion test for 30 days in sea water

\section{E. Life Span Assessment of Heat Exchanger}

The life span estimation of a copper tube stack can provide the schedule for major overhauling or renewal requirements of a heat exchanger in line with the overall refit/renovation plan of the vessel based on corrosion rate. In the present study, it is observed that the curves for weight losses as well as corrosion rates become flat after 30 days of operation both in river and sea water. Here, two postulates may be taken into consideration, such as: (i) the flat rate of corrosion obtained after 30 days may continue throughout the lifetime of the heat exchanger, or (ii) the ship's crew may carry out chemical cleaning every after 30 days to avoid bio-fouling or marine growth for maintaining heat transfer coefficient intact or at least within the cooling requirement level. The second option is always preferable to marine engineers, because the engine life is more important than that of heat exchanger based on cost and service values. Accordingly, on completion of the first cycle of the corrosion test, i.e., after 30 days operations, the tubes are cleaned as a part of routine maintenance using standard chemical agents and the corrosion tests are carried out for the second cycle of 30 days. Similarly, another series of tests have been done for the third cycle of 30 days operations.

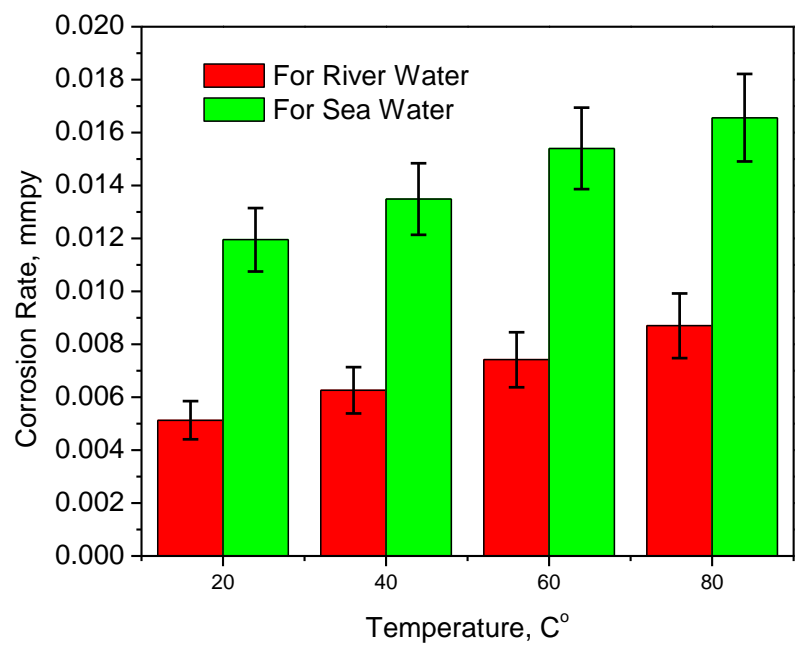

Figure 11: Mean corrosion rates of three operating cycles along with error level against operating temperatures for river and sea water with the flow velocity of $2.0 \mathrm{~m} / \mathrm{s}$

The life span of tube stack is then assessed with the combined experimental results of three corrosion cycles. The mean corrosion rates of the three cycles for four operating temperatures are presented in Figure 11. Out of mean corrosion rates for four operating temperatures, the highest mean value is obtained for $80^{\circ} \mathrm{C}$, i.e., $8.7 \times$ $10^{-3} \mathrm{mmpy}$ with an error level of $6 \%$ for river water and $16.6 \times 10^{-3} \mathrm{mmpy}$ with an error level of $5 \%$ for sea water. Since the vessel needs to travel nearly one-fourth in the river and three-fourth at sea route, the life span is calculated taking corrosion rates of river and sea water with the weightage values $1: 3$ and incorporating the allowance for error level. By this way, the life span is found to be 24 years considering the uniform loss of thickness, but practically it does not happen, because the failure of heat exchanger tube normally originates at the pitting location. Therefore, considering the pitting susceptibility allowance of $>15 \%$, the estimated life span comes down to 20 years which is reasonable with the designed life of the ship.

\section{CONCLUSIONS}

This work presents a comprehensive experimental analysis of locally manufactured marine engineering item such as, shell and tube type heat exchanger for its life span assessment based on corrosion behavior. Based on the results obtained in the present work, the notable findings can be summarized as follows:

i. Copper tube of heat exchanger corroded both in river water and sea water environments. The rate of corrosion was higher at the beginning of heat exchanger operation for both the environments. 
ii.

Corrosion on copper tube in sea water environment was about three times higher than that of river water environment due to water chemistry including dissolved oxygen, TDS, TSS, chloride, conductivity, etc.

iii. Corrosion increased with the increase of operating temperature, but no linear relation was obtained. However, the average weight loss gradient was found to be $6.98 \times 10^{-6} \mathrm{~g} / \mathrm{cm}^{2} /{ }^{\circ} \mathrm{C}$ in river water while in sea water it was $10.35 \times 10^{-6} \mathrm{~g} / \mathrm{cm}^{2} /$ ${ }^{\circ} \mathrm{C}$.

iv. The effect of velocity was observed for both environments, and the corrosion rates were found to be increased by $6.8 \%$ in river water and $14.5 \%$ in sea water with the change of velocity from $1.0 \mathrm{~m} / \mathrm{s}$ to $2 \mathrm{~m} / \mathrm{s}$.

v. The life span of copper tube (18 BWG) of heat exchanger was estimated to be 20 years with the three-fourth period of operations at sea and the one-fourth at river water, which was proportionate to the designed life of ship.

\section{ACKNOWLEDGEMENTS}

Authors profoundly acknowledge the financial support of MIST, material and equipment support of KSY Ltd and laboratory support of BUET as well as MIST to conduct this research.

\section{REFERENCES}

Abdallah, M. M. A., Maayta, A.K., Qudah, M.A. A. \& Rawashdeh, N.A.F. A. (2009). Corrosion Behavior of Copper in Chloride Media, The Open Corrosion Journal, 2, 71-76. doi:10.1016/j.matdes.2008.10.015

Baboian, R. (2005). Corrosion Tests and Standards - Application and Interpretation. ASTM International, Philadelphia, USA

Collini, L. (2012). Copper Alloys - Early Applications and Current Performance - Enhancing Processes. InTech Janeza Trdine 9, 51000 Rijeka, Croatia.

Cramer, S.D. \& Covino, B.S. (2005). Corrosion: Materials. ASM Handbook, Volume 13B, ASM International. Materials Park, Ohio 44073-0002 USA.

Davis, J. R. (2001). Copper and Copper Alloys. ASM Specialty Handbook, ASM International, Materials Park, Ohio 440730002, USA.

Farro, N. W., Veleva, L. and Aguilar, P. (2009). Copper Marine Corrosion: I. Corrosion Rates in Atmospheric and Seawater Environments of Peruvian Port, The Open Corrosion Journal, 2, 114-122.

Francis, R. (2010). Corrosion of Copper and its Alloys - A Practical Guide for Engineers. NACE International, 1440 South Creek Drive, Houston, Texas, USA.

Gerasimov, V. V., \& Rozenfeld, I. L. (1958). Effect of temperature on the rate of corrosion of metals. Bulletin of the Academy of Sciences of the USSR Division of Chemical Science, 6(10), 1192-1197. doi:10.1007/bf01167386

Graedel, T. E., Nassau, K. \& Franey, J. P. (1987). Copper patinas formed in the atmosphere-I. Introduction, Corrosion Science, 27(7), 639-657. doi:10.1016/0010-938x(87) 900473

Gudas, J. P., \& Hack, H. P. (1979). Parametric Evaluation of Susceptibility of Cu-Ni Alloys to Sulfide Induced Corrosion in Sea Water. Corrosion, 35(6), 259-264. doi:10.5006/00109312-35.6.259

Hedin, A., Johansson, A. J., Lilja, C., Boman, M., Berastegui, P., Berger, R., \& Ottosson, M. (2018). Corrosion of copper in pure O 2 -free water? Corrosion Science, 137, 112. doi:10.1016/j.corsci.2018.02.008

Hultquist, G., Szakálos, P., Graham, M. J., Belonoshko, A. B., Sproule, G. I., Gråsjö, L., ... Rosengren, A. (2009). Water Corrodes Copper. Springer, Catalysis Letters, 132(3-4), 311-316. doi:10.1007/s10562-009-0113-x

Hultquist, G., Graham, M. J., Szakalos, P., Sproule, G. I., Rosengren, A., \& Gråsjö, L. (2011). Hydrogen gas production during corrosion of copper by water. Elsevier, Corrosion Science, 53(1), 310-319. doi:10.1016/j.corsci. 2010.09.037

Hultquist, G. (2015). Why copper may be able to corrode in pure water. Corrosion Science, 93, 327-329. doi:10.1016/ j.corsci.2015.01.002

Hultquist, G., Graham, M. J., Kodra, O., Moisa, S., Liu, R., Bexell, U., \& Smialek, J. L. (2015). Corrosion of copper in distilled water without $\mathrm{O}_{2}$ and the detection of produced hydrogen. Corrosion Science, 95, 162167. doi:10.1016/j.corsci. 2015.03.009

Imai, M., Yamashita, Y., Futatsuki, T., Shiohara, M., Kondo, S., \& Saito, S. (2009). Effect of Dissolved Oxygen on $\mathrm{Cu}$ Corrosion in Single Wafer Cleaning Process. Japanese Journal of Applied Physics, 48(4), 04C023. doi:10.1143/jjap. $48.04 \mathrm{c} 023$

Kong, D., Dong, C., Xiao, K., \& Li, X. (2017). Effect of temperature on copper corrosion in high-level nuclear waste environment. Transactions of Nonferrous Metals Society of China, 27(6), 1431-1438. doi:10.1016/s1003-6326(17) 60165-1

Kristiansen, H. (1977). Corrosion of Copper by Water of Various Temperatures and carbon dioxide contents. Materials and Corrosion/Werkstoffe Und Korrosion, 28(11), 743748. doi:10.1002/maco. 19770281102

Kuźnicka, B. (2009). Erosion-corrosion of heat exchanger tubes. Engineering Failure Analysis, 16(7), 23822387. doi:10.1016/j.engfailanal.2009.03.026

Lee, S. K., Hsu, H. C., \& Tuan, W. H. (2016). Oxidation Behavior of Copper at a Temperature below $300{ }^{\circ} \mathrm{C}$ and the Methodology for Passivation. Materials Research, 19(1), 51-56. doi:10.1590/1980-5373-mr-2015-0139

Leygraf, C., Chang, T., Herting, G., \& Odnevall Wallinder, I. (2019). The Origin and Evolution of Copper Patina Colou. Corrosion Science. doi:10.1016/j.corsci.2019.05.025

Melchers, R. E. (2001). Temperature Effect on Seawater Immersion Corrosion of 90:10 Copper-Nickel Alloy. CORROSION, 57(5), 440-451. doi:10.5006/1.3290368

Miller, R. L., Bradford, W. L., \& Peters, N. E. (1988). Specific Conductance: Theoretical Considerations and Application to Analytical Quality Control. In U.S. Geological Survey Water-Supply Paper. Retrieved from http://pubs.usgs.gov/ wsp/2311/report.pdf

Mor, E. D., \& Beccaria, A. M. (1979). Effects of temperature on the corrosion of copper in sea water at different hydrostatic pressures. Congresso Nazionale della Societi, Werkstoffe und Korrosion, 30, 551-558.

Nunez, L., Reguera, E., Corvo, F., Gonzalez, E. and Vazquez, C. (2005). Corrosion of copper in sea water and its aerosols in a tropical island. Elsevier, Corrosion Science, 47, 461-484. doi:10.1016/j.corsci.2004.05.015

Orozco-Cruz, R., Ávila, E., Mejía, E., Pérez, T., Contreras, A. and Martínez, R. G. (2017). In situ Corrosion Study of Copper and Copper-Alloys Exposed to Natural Seawater of the Veracruz Port (Gulf of Mexico). Int. J. of Electrochemical Science, 12, $3133-3152$.

Pehkonen, S. O., Palit, A., \& Zhang, X. (2002). Effect of Specific Water Quality Parameters on Copper Corrosion. CORROSION, 58(2), 156-165. doi:10.5006/1.3277316

Poulson, B. (1993). Advances in understanding hydrodynamic effects on corrosion. Corrosion Science, 35(1-4), 655- 
665. doi:10.1016/0010-938x(93)90201-q

Rahman, M. M. (2017). An Appraisal of Shipbuilding Prospects in Bangladesh. Elsevier, Procedia Engineering, 194, $224-$ 231. doi: 10.1016/j.proeng.2017.08.139

Rahmanto, W. H., Gunawan and Nuryanto, R. (2002). Corrosion rate of copper and iron in seawater based on resistance measurement. Journal of Coastal Development, 5(2), 67-74.

Roy, S., Coyne, J. M., Novak, J. A., and Edwards, M. A. (2018). Flow-induced failure mechanisms of copper pipe in potable water systems. Corrosion Reviews, 36(5), 449-481. DOI: https://doi.org/10.1515/corrrev-2017-0120

Sabri, M. A. M., Sulong, A. B., Chin, F. K. \& Sahari, J. (2012). Effect of Corrosion on the Electrical Conductivity of Metals and Polymer Composite, Jurnal Teknologi (Sciences \& Engineering) 59, Suppl 2, 81-85.

Schumacher, M. (1979). Seawater corrosion handbook. Noyes Data Corp., Park Ridge, N. J., USA

Simpson, J. P., \& Schenk, R. (1987). Hydrogen evolution from corrosion of pure copper. Corrosion Science, 27(12), 13651370. doi:10.1016/0010-938x(87)90131-4

Srivastava, A., \& Balasubramaniam, R. (2005). Microstructural characterization of copper corrosion in aqueous and soil environments. Materials Characterization, 55(2), 127135. doi:10.1016/j.matchar.2005.04.004

Szakálos, P., Hultquist, G., \& Wikmark, G. (2007). Corrosion of Copper by Water. Electrochemical and Solid-State Letters, 10(11), C63. doi:10.1149/1.2772085

Utanohara, Y., \& Murase, M. (2019). Influence of flow velocity and temperature on flow accelerated corrosion rate at an elbow pipe. Nuclear Engineering and Design, 342, 20-28. doi:10.1016/j.nucengdes.2018.11.022

Wan, Y., Wang, X., Sun, H., Li, Y., Zhang, K. and Wu, Y. (2012). Corrosion Behavior of Copper at Elevated Temperature, Int. J. Electrochem. Sci., 7, $7902-7914$.

Yatsenko, E. A., Zubekhin, A. P., \& Nepomnyashchev, A. A. (1999). Protection of copper against high-temperature corrosion. Glass and Ceramics, 56(9-10), 295-297. doi:10.1007/bf02681380

Zakowski, K., Narozny, M., Szocinski, M., \& Darowicki, K. (2014). Influence of water salinity on corrosion risk - the case of the southern Baltic Sea coast. Environmental Monitoring and Assessment, 186(8), 4871-4879. doi:10.1007/s10661-014-3744-3 